\title{
Implementation of a Model of Bodily Fluids Regulation
}

\author{
Julie Fontecave-Jallon ${ }^{1} \cdot$ S. Randall Thomas ${ }^{2}$
}

Received: 9 January 2015/ Accepted: 27 March 2015/Published online: 3 May 2015

(C) The Author(s) 2015. This article is published with open access at Springerlink.com

\begin{abstract}
The classic model of blood pressure regulation by Guyton et al. (Annu Rev Physiol 34:13-46, 1972a; Ann Biomed Eng 1:254-281, 1972b) set a new standard for quantitative exploration of physiological function and led to important new insights, some of which still remain the focus of debate, such as whether the kidney plays the primary role in the genesis of hypertension (Montani et al. in Exp Physiol 24:41-54, 2009a; Exp Physiol 94:382-388, 2009b; Osborn et al. in Exp Physiol 94:389-396, 2009a; Exp Physiol 94:388-389, 2009b). Key to the success of this model was the fact that the authors made the computer code (in FORTRAN) freely available and eventually provided a convivial user interface for exploration of model behavior on early microcomputers (Montani et al. in Int J Bio-med Comput 24:41-54, 1989). Ikeda et al. (Ann Biomed Eng 7:135-166, 1979) developed an offshoot of the Guyton model targeting especially the regulation of body fluids and acid-base balance; their model provides extended renal and respiratory functions and would be a good basis for further extensions. In the interest of providing a simple, useable version of Ikeda et al.'s model and to facilitate further such extensions, we present a practical implementation of the model of Ikeda et al. (Ann Biomed Eng 7:135-166, 1979), using the ODE solver Berkeley Madonna.
\end{abstract}

Electronic supplementary material The online version of this article (doi:10.1007/s10441-015-9250-3) contains supplementary material, which is available to authorized users.

http://www.berkeleymadonna.com

S. Randall Thomas

stephen-randall.thomas@u-psud.fr

Julie Fontecave-Jallon

Julie.Fontecave@imag.fr

1 CNRS, TIMC-IMAG Laboratory CNRS UMR 5525, PRETA Team, University Joseph FourierGrenoble 1, 38041 Grenoble, France

2 IR4M UMR8081 CNRS, University Paris-Sud, Orsay, France 
Keywords Computational physiology $\cdot$ Acid-base balance $\cdot$ Mathematical modelling · Virtual physiological human (VPH)

\section{Introduction}

Computational modelling in physiology has contributed to many significant breakthroughs, but the models themselves have usually not become working tools for experimentalists nor even for other modellers outside the developer's own group. We provide here a practical implementation of one of the classic and most complete models of body fluid and acid-base regulation, and we give several examples of the use of the model. We give the complete model description in the language of Berkeley Madonna, which is very easy to read and can readily be converted for other numerical solvers. Physiologists and clinicians will find this model easy to use, and this complete example will facilitate extensions in order to simulate related clinical situations or new experimental findings.

Inspired by the classic model of blood pressure regulation by Guyton et al. (1972a), Ikeda et al. (1979) adopted the same symbolic representation to illustrate model structure, but since their focus was on body fluids and acid-base balance, which have a slower time course than, say, autonomic regulation of cardiovascular variables, they simplified the representation of the cardiovascular system but greatly extended the renal and respiratory systems. Their model consists of a set of nonlinear differential and algebraic equations with more than 200 variables and has subsystems for circulation, respiration, renal function, and intra- and extra-cellular fluid spaces.

\section{Materials and Methods}

\subsection{Model Description}

The original article of Ikeda et al. (1979) describes the details of the model, so we will not give a complete description here (the program code, Online Resource 01, given in the Electronic Supplementary Material and described in the Appendix, has all the explicit equations); our implementation closely follows the description in their article, especially in their diagrams of the seven blocks that constitute the model, namely, the circulation and body fluids (blocks 1, 3, and 4), respiration (block 2), and renal function (blocks 5, 6, and 7). Initial values and many other details are given not only in the text but also on the diagrams and in the tables of the original article. Here, we give just a brief explanation of the basic content of the model and Ikeda et al.'s general strategy.

As in Ikeda et al. (1979), the model assumes a healthy male of approximately $55 \mathrm{~kg}$ body weight, and parameter values used here are those given in the original article. Calibration of the model for other body weights or for females would be a valuable extension of the model but is beyond the goals of the present work. Such extension would involve re-calibration not only of extracellular and intracellular fluid volumes (and thus with impact on solute contents of those compartments), but 
also of less straightforward parameters such as metabolic rate, respiratory volume, cardiac output, and the like.

The cardiovascular/circulatory (CV) system, quite complex in Guyton's model, was considerably simplified by Ikeda et al. (1979) to a simple steady state that represents the system's state after settling from transient local autoregulation or stress relaxation.

By contrast with the simplified CV system, and in keeping with their focus on acid-base and fluid physiology, Ikeda et al. (1979) included much more elaborate representations of the respiratory system, intracellular and extracellular electrolytes and solutes, and of course the kidney. For example:

- Alveolar ventilation (VI) is calculated as a function of blood $\mathrm{pH}, \mathrm{P}_{\mathrm{CO}_{2}}$, and $\mathrm{P}_{\mathrm{O}_{2}}$;

- The blood buffer system is treated using the Henderson-Hasselbalch equation, an equation for the oxygen saturation curve, and an equation for the in vivo $\mathrm{CO}_{2}$ dissociation curve, thus the model takes account of the haemoglobin buffer system, the Bohr effect, and the Haldane effect;

- The model treats intra- and extra-cellular electrolytes and acid-base balance and also glucose metabolism and insulin secretion-disorders of glucose metabolism can be modelled by varying the parameters CGL1, CGL2 and CGL3;

- Plasma osmolality in the model depends on the concentrations not only of sodium, potassium, glucose, and urea, but also of mannitol, included in the model because of its frequent therapeutic use;

- The renal blocks treat reabsorption and excretion not only of water, sodium, and potassium, but also of bicarbonate, calcium, magnesium, phosphate, and organic acids; proximal tubule reabsorption depends on volume expansion or pressure diuresis (THDF); aldosterone is assumed to act on the distal tubule to increase sodium reabsorption, decrease potassium secretion, and increase excretion of titratable acid; urine $\mathrm{pH}$ and excretion of ammonia, titratable acid, phosphate, and organic acids are included in the model; glomerular filtration rate (GFR), represented as a sigmoid function of arterial pressure, is controlled by extracellular volume (VEC) and depends on antidiuretic hormone (ADH) and aldosterone (ALD) and on THDF;

- The renin-angiotensin-aldosterone system (RAAS) is represented here simply as a transfer function by which ALD secretion depends on extracellular fluid (ECF) potassium concentration, tubular sodium concentration, arterial pressure, and volume receptor signals.

In addition to this incomplete list, the model contains many other interesting features that the reader should glean from the original Ikeda et al. (1979) article.

\subsubsection{Berkeley Madonna Description}

Berkeley Madonna is a fast, robust, multi-platform solver of systems of ordinary differential-algebraic equations. Compared with other such solvers, it is extremely easy to program (a simple list of the equations in any order), has a very effective user interface for plotting or tabulating the results and varying the parameters 
(simple "sliders" can be easily defined to vary individual model variables or parameters, with instant re-run of the model), and it has proven to be very fast compared to other solvers we have used.

\section{Results}

To demonstrate several interesting features of the model and also to show that the Berkeley Madonna implementation presented here is an accurate representation of the Ikeda et al. model, we show that it faithfully reproduces the results of four

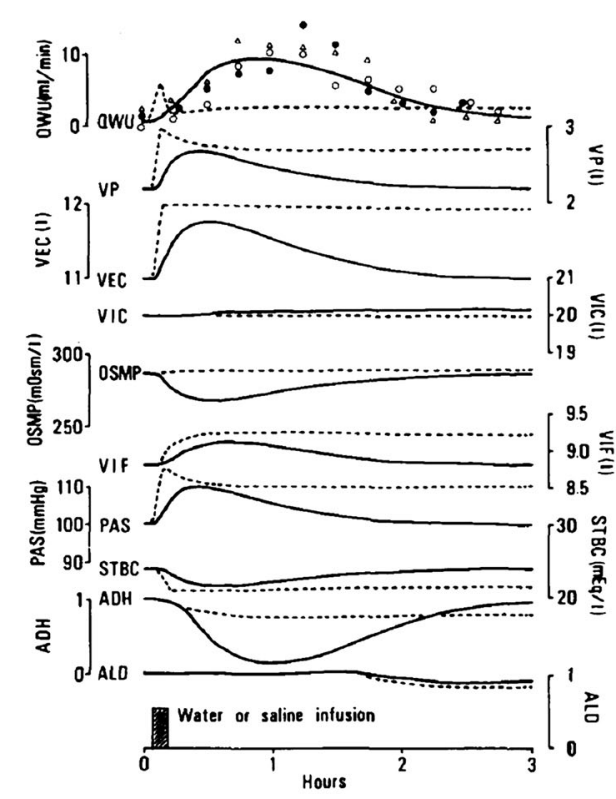

(A)

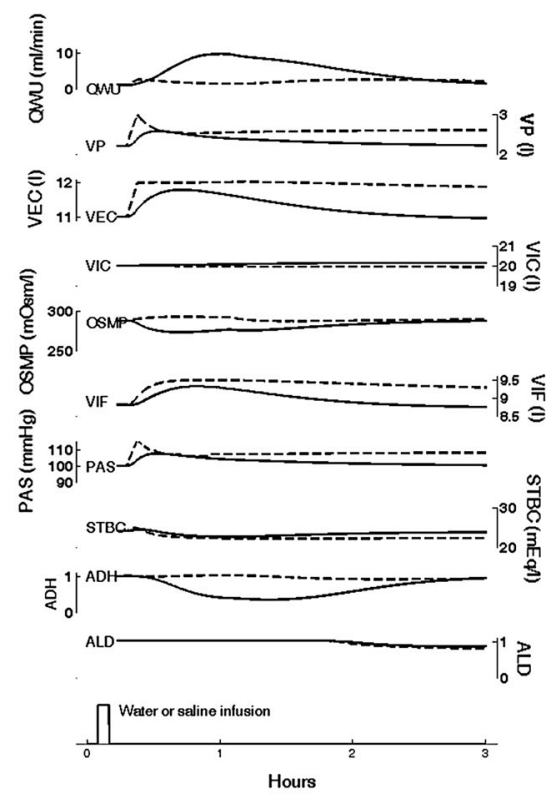

(B)

Fig. 1 a Simulation of oral water intake (solid lines) and intravenous infusion of physiological saline (dashed lines), both at a rate of $1000 \mathrm{ml}$ per $5 \mathrm{~min}$ (see Fig. 10 in Ikeda et al. (1979)). b The same simulations were carried out in Berkeley-Madonna. We simulate, during $3 \mathrm{~h}$, the responses of body fluid and kidney parameters to acute water loading (solid lines) at a rate of $200 \mathrm{ml} / \mathrm{min}$ during $5 \mathrm{~min}$ (rate of drinking, QIN=0.2 1/min from $\mathrm{t}=5$ to $10 \mathrm{~min}$ ) and to intravenous normal saline infusion (dashed lines), solution of $0.9 \% \mathrm{w} / \mathrm{v}$ of $\mathrm{NaCl}$, containing $154 \mathrm{mEq} / 1$ of $\mathrm{Na}^{+}$and $\mathrm{Cl}^{-}$, at the same rate during $5 \mathrm{~min}$ (from $\mathrm{t}=5$ to $10 \mathrm{~min}$, the rate of intravenous water input was QVIN $=0.21 / \mathrm{min}$, and intake rate of sodium and chloride was $\mathrm{YNIN}=\mathrm{YCLI}=30.8 \mathrm{mEq} / \mathrm{min}$ ). For the simulation of oral water intake (Online Resource 02), the user must replace the following line of BM code: QIN $=0.001$ with: $\mathrm{QIN}=\mathrm{IF}(\mathrm{TIME} \geq 5$ AND TIME $\leq 10$ ) THEN 0.2 ELSE 0.001. For the simulation of intravenous infusion of physiological saline (Online Resource 03), the user must replace the following lines of BM code: $\mathrm{QVIN}=0, \mathrm{YCLI}=0.1328$ and YNIN $=0.12$ with: QVIN $=\mathrm{IF}(\mathrm{TIME} \geq 5$ AND $\mathrm{TIME} \leq 10)$ THEN 0.2 ELSE 0, YCLI $=$ IF (TIME $\geq 5$ AND TIME $\leq 10$ ) THEN 154*0.2 ELSE 0.1328, YNIN $=$ IF $($ TIME $\geq 5$ AND TIME $\leq 10)$ THEN $154 * 0.2$ ELSE 0.12 . We observe the rate of urinary output (QWU), the plasma volume (VP), the volume of extracellular fluid (VEC), the intracellular fluid volume (VIC), the plasma osmolality (OSMP), the interstitial fluid volume (VIF), the systemic arterial pressure (PAS), the standard bicarbonate at $\mathrm{pH}=7.4$ (STBC), the effect of antidiuretic hormone (ADH), and the effect of aldosterone (ALD) 


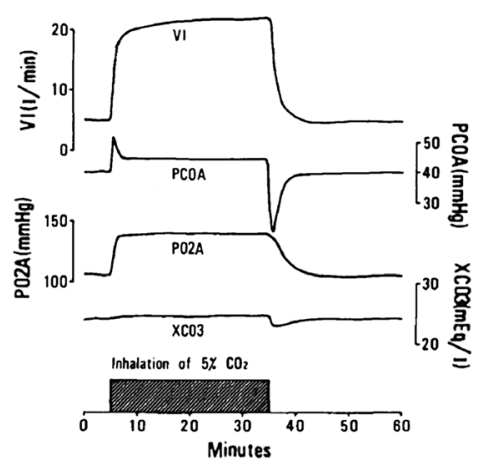

(A)

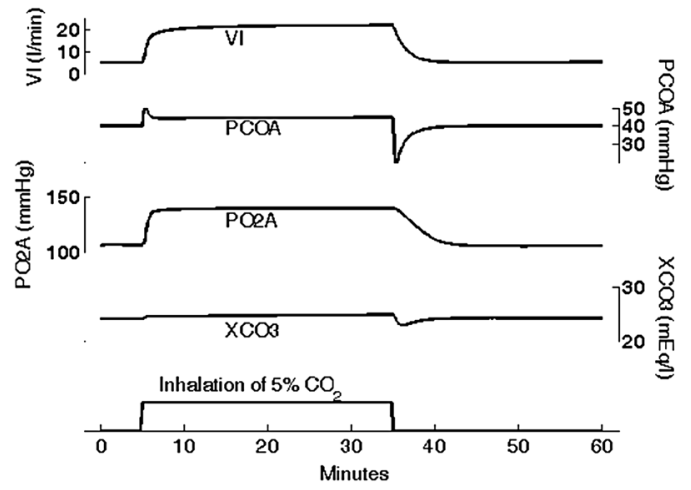

(B)

Fig. 2 a Simulation of the transient response of the respiratory system to $5 \% \mathrm{CO}_{2}$ inhalation (see Fig. 11 in Ikeda et al. Ikeda et al. (1979)). b The same simulation was carried out in Berkeley-Madonna (Online Resource 04). We simulate, during $1 \mathrm{~h}$, the transient response of the respiratory parameters to the inhalation of $5 \% \mathrm{CO}_{2}$ in air over $30 \mathrm{~min}$ (volume fraction of $\mathrm{CO}_{2}$ in dry inspired gas $\mathrm{FCOI}=0.05$ from $\mathrm{t}=5$ to $35 \mathrm{~min}$ ). The user must replace the following line of $\mathrm{BM}$ code: $\mathrm{FCOI}=0$ with: $\mathrm{FCOI}=\mathrm{IF}$ (TIME $\geq 5$ AND TIME $\leq 35$ ) THEN 0.05 ELSE 0. We observe the alveolar ventilation (VI), the pressure of $\mathrm{CO}_{2}$ and $\mathrm{O}_{2}$ in the alveoli (PCOA and PO2A), and the concentration of bicarbonate of the extracellular fluid (XCO3)

simulations whose results are shown in the figures of their article. The BM codes used to generate the results of the following simulations are all provided as Electronic Supplementary Material (see Appendix).

Figure 1 shows the results of a simulation of oral water intake ( 11 over 5 min) and intravenous infusion of physiological saline; the left panel shows Fig. 10 from the Ikeda article, and the right panel shows results from our BM model, which are clearly a good match to those in their article.

Figure 2 shows the transient response of respiratory parameters to inhalation of $5 \% \mathrm{CO}_{2}$ over 30 minutes; the left panel shows Fig. 11 from the Ikeda article, and the right panel shows results from our BM model.

Figure 3 shows results from a simulation of glucose tolerance test (infusion of $50 \mathrm{~g}$ of glucose over $1 \mathrm{~h}$ ), including insulin secretion due to a concomitant decrease of extracellular fluid potassium concentration; as above, the left panel shows Fig. 12 from the Ikeda article, and the right panel shows the corresponding results from our BM model.

Figure 4 shows, in acid-base disturbances, the central role of the kidney in the compensatory reactions of the body when the normal response of respiration does not occur. The long-term time course of the model behavior in respiratory acidosis or alkalosis is depicted on the $\mathrm{pH}-\left[\mathrm{HCO}_{3}\right]$ diagram. The response to $10 \% \mathrm{CO}_{2}$ inhalation and the response to hyperventilation are observed. The right panel shows the results from our BM model, which are in good agreement with the results of Ikeda article, shown on the left panel. The sequence of steps necessary to reproduce this figure with BM implementation is detailed in the specific BM code listing (Online Resources 06 \& 07). 


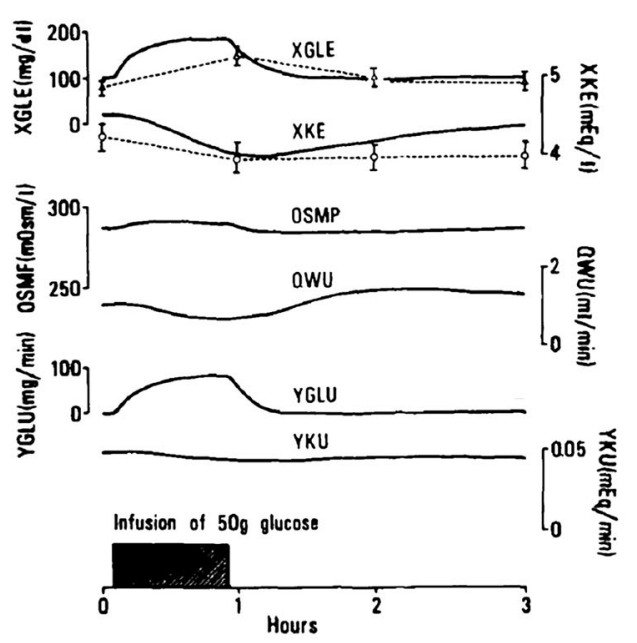

(A)

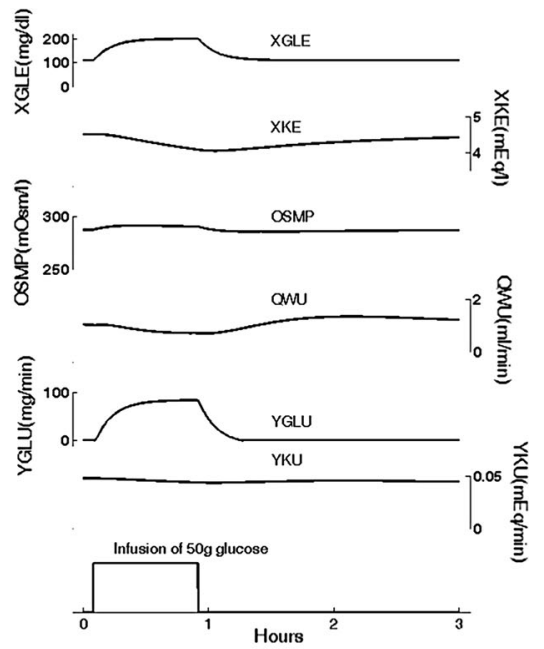

(B)

Fig. 3 a Simulation (Fig. 12 in Ikeda et al. Ikeda et al. (1979)) of the glucose tolerance curve with the extracellular fluid potassium concentration. b The same simulation was carried out in Berkeley-Madonna (Online Resource 05). We simulate, during $3 \mathrm{~h}$, a test of glucose metabolism, corresponding to the infusion of glucose at a rate of $1 \mathrm{~g} / \mathrm{min}$ during $50 \mathrm{~min}$ (intake rate of glucose YGLI $=1000$ from $\mathrm{t}=5$ to $\mathrm{t}=55 \mathrm{~min}$ ). The user must replace the following line of the BM code: YGLI $=0$ with: YGLI $=\mathrm{IF}$ (TIME $\geq 5$ AND TIME $\leq 55$ ) THEN 1000 ELSE 0. We observe the ECF glucose concentration (XGLE), the ECF potassium concentration (XKE), the plasma osmolality (OSMP), the rate of urinary output (QWU), the renal excretion of glucose (YGLU), and the rate of renal loss of potassium (YKU)

\section{Discussion}

Efforts towards reusability and interoperability have made progress in recent years, not only in the modeling of kidney physiology (Thomas 2009) but also in the wider context of physiology and systems biology (Hunter et al. 2013). For instance, SBML (the Systems Biology Markup language) ${ }^{1}$ (Hucka et al. 2003) is widely used for metabolic networks and models of cell signal transduction, the CellML repository ${ }^{2}$ contains several hundred marked-up legacy models (mostly at the level of membrane transport or signal transduction), the JSim Consolidated Model Database $^{3}$ indexes 73390 models across five archives, and annotation tools such as the RICORDO ${ }^{4}$ resource (de Bono et al. 2011) and the ApiNATOMY ${ }^{5}$ (de Bono et al. 2012) project now facilitate the sharing (and even the merging) of physiology and systems biology models.

The present work complements previous re-implementations of the Ikeda model; e.g., a Pascal version was used in teaching at the University of Limburg, Maastricht

\footnotetext{
1 http://sbml.org.

2 https://models.cellml.org/cellml.

3 http://physiome.org/jsim/db/.

4 http://www.ricordo.eu.

5 http://apinatomy.org.
} 


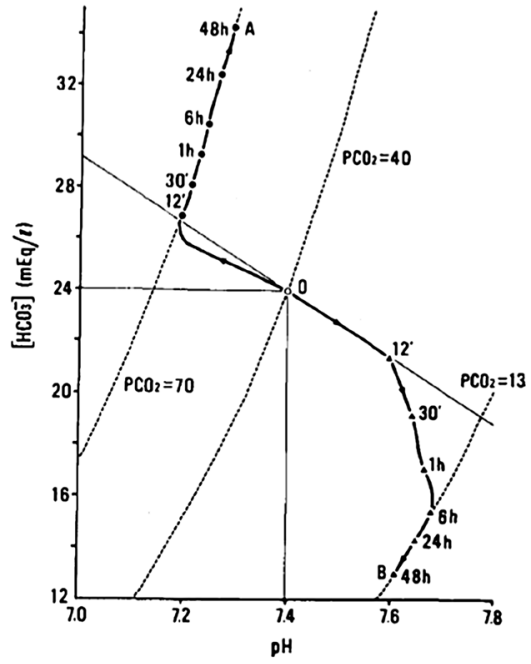

(A)

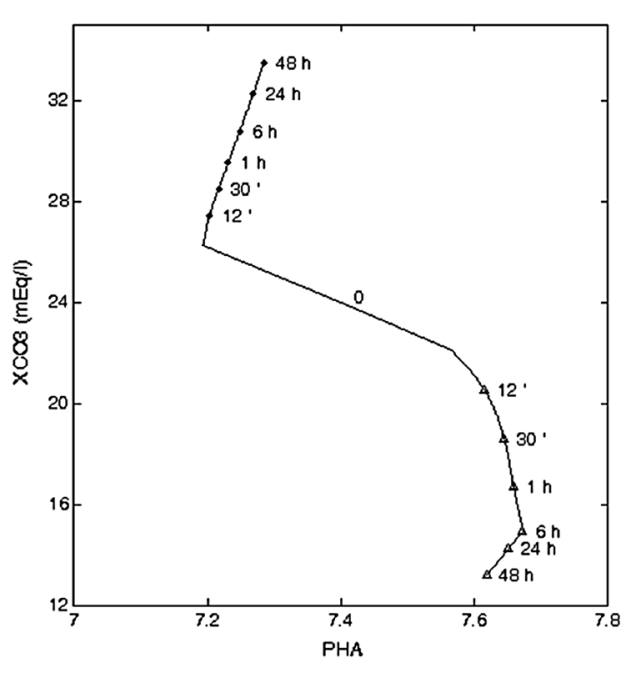

(B)

Fig. 4 a Simulation (Fig. 13 in Ikeda et al. Ikeda et al. (1979)) of respiratory acidosis and alkalosis with renal compensation. Point $O$ shows the normal value of the model of the $\mathrm{pH}-\left[\mathrm{HCO}_{3}\right]$ plane. Triangle indicates the plotting of simulated response to $10 \% \mathrm{CO}_{2}$ inhalation for $48 \mathrm{~h}$, and Filled circle indicates that of hyperventilation, in which VI was fixed at $151 / \mathrm{min}$. Equi-pressure lines of $\mathrm{PCO}_{2}$ are shown with dotted lines for the $\mathrm{PCO}_{2}$ values of $13.3,40.0$, and $73.0 \mathrm{mmHg}$. b The same simulations were carried out in Berkeley-Madonna. We first simulate (Online Resource 06), during $48 \mathrm{~h}$, the response to $10 \% \mathrm{CO}_{2}$ inhalation (volume fraction of $\mathrm{CO}_{2}$ in dry inspired gas FCOI at the value of 0.1 , rather than 0 , during the whole simulation and equation (1) unmodified). The bicarbonate concentration of the extracellular fluid (XCO3) and the $\mathrm{pH}$ of arterial blood (PHA) are measured at various times from 12 min to $48 \mathrm{~h}$ and plotted with Triangle line. We then simulate (Online Resource 07) during $48 \mathrm{~h}$ the response to hyperventilation, in which VI was raised to three times normal (alveolar ventilation VI is kept constant to $15 \mathrm{l} / \mathrm{min}, \mathrm{VI}=15$, replacing equation (1) of the $\mathrm{BM}$ code during the whole simulation). The volume fraction of $\mathrm{CO}_{2}$ in dry inspired gas FCOI is set at its normal value 0 . XCO3 and PHA are measured at various times from $12 \mathrm{~min}$ to $48 \mathrm{~h}$ and plotted with Filled circle line

(Min (1982); Pascal source code in Min (1993)), and extensions of parts of the Ikeda model were used in the Golem simulator (Kofranek et al. 2001). The present Berkeley Madonna version also complements our re-implementations of the early Guyton models (Hernandez et al. 2011; Moss et al. 2012; Thomas et al. 2008) and recent models focused on the kidney itself (Karaaslan et al. 2005, 2014; Moss et al. 2009; Moss and Thomas 2014) or on the role of the kidney in blood pressure regulation (Averina et al. 2012; Beard and Mescam 2012). We provide here a convenient implementation of the Ikeda et al. (1979) model in order to facilitate not only its use in its original form but also to enable its extension. One such improvement would be the incorporation of a more complete model of the RAAS system, which is now much better understood and for which a detailed model has recently been published (Guillaud and Hannaert 2010).

Acknowledgments This work was funded by the following Grants: VPH NoE (EU FP7, Grant 23920) (http://cordis.europa.eu/fp7/ict/); SAPHIR project, Grant ANR-06-BYOS-0007-01, Agence Nationale de la Recherche (http://www.agence-nationale-recherche.fr/en/); and BIMBO project, Grant ANR-09SYSCOMM-002, Agence Nationale de la Recherche (http://www.agence-nationale-recherche.fr/en/). 
Open Access This article is distributed under the terms of the Creative Commons Attribution 4.0 International License (http://creativecommons.org/licenses/by/4.0/), which permits unrestricted use, distribution, and reproduction in any medium, provided you give appropriate credit to the original author(s) and the source, provide a link to the Creative Commons license, and indicate if changes were made.

\section{Appendix}

\section{Program Code}

The source code for our implementation of the model of Ikeda et al. (1979), using the ODE solver Berkeley Madonna, is available as Supplementary Material on the website of Acta Biotheoretica. In addition to the basic version that corresponds strictly to the description in the original article, we also provide variants used to produce the figures of the present article.

We release the model codes under the CeCill free software license agreement (a copy of the CeCill free software license agreement is included as Online Resource 00, file: ESM_00).

We provide the following Berkeley Madonna source code files:

1. Online Resource 01 (file: "ESM_01"): Basic code for simulation of the model in steady-state (file: "ESM_01")

2. Oral water intake and intravenous infusion of physiological saline (Fig. 10 of Ikeda et al. (1979))

- Online Resource 02, file: "ESM_02"-Simulation of water intake at a rate of $1000 \mathrm{ml}$ per $5 \mathrm{~min}$.

- Online Resource 03, file: "ESM_03"-Simulation of intravenous infusion of physiological saline at a rate of $1000 \mathrm{ml}$ per $5 \mathrm{~min}$.

3. Transient response of the respiratory system to $5 \% \mathrm{CO}_{2}$ inhalation (Fig. 11 of Ikeda et al. (1979))

- Online Resource 04, file: "ESM_04"-Simulation of the inhalation of $5 \%$ $\mathrm{CO}_{2}$ in air over $30 \mathrm{~min}$.

4. Glucose tolerance curve with the extracellular potassium concentration (Fig. 12 of Ikeda et al. (1979))

- Online Resource 05, file: "ESM_05"-Simulation during $3 \mathrm{~h}$ of a test of glucose metabolism, corresponding to the infusion of glucose at a rate of $1 \mathrm{~g} / \mathrm{min}$ during $50 \mathrm{~min}$.

5. Respiratory acidosis and alkalosis with renal compensation (Fig. 13 of Ikeda et al. (1979)).

- Online Resource 06, file: "ESM_06"-Simulation of $10 \% \mathrm{CO}_{2}$ inhalation during $48 \mathrm{~h}$.

- Online Resource 07, file: "ESM_07"-Simulation of ventilation at 15 1/min during $48 \mathrm{~h}$. 


\section{List of Variables}

Here we give the table of variables, with units and normal or initial values. STPD refers to "standard temperature and pressure, dry", denoting a volume of dry gas at $0{ }^{\circ} \mathrm{C}$ and a pressure of $760 \mathrm{mmHg}$.

\begin{tabular}{|c|c|c|}
\hline Symbol & Definition & Normal value \\
\hline ADH & Effect of antidiuretic hormone (ratio to normal) & 1 \\
\hline ALD & Effect of aldosterone (ratio to normal) & 1 \\
\hline $\mathrm{CFC}$ & Capillary filtration coefficient & $0.007 \mathrm{l} / \mathrm{min} / \mathrm{mmHg}$ \\
\hline CGL1 & Parameter of glucose metabolism & 1 \\
\hline CGL2 & Parameter of glucose metabolism & 1 \\
\hline CGL3 & Parameter of glucose metabolism & 0.03 \\
\hline CHEI & Transfer coefficient of hydrogen ion into ICF & 5 \\
\hline CKAL & Weight of effect of XKE on aldosterone secretion & 0.5 \\
\hline CNAL & Weight of effect on YNH on aldosterone secretion & 0.1 \\
\hline CPAL & Weight of effect of PAS on aldosterone secretion & 0.01 \\
\hline CPVL & Weight of effect of PVP on aldosterone secretion & 0.1 \\
\hline COAD & Weight of effect of OSMP on ADH secretion & 0.5 \\
\hline CPAD & Weight of effect of PVP on ADH secretion & 1.0 \\
\hline CKEI & Potassium transfer coefficient from ECF to ICF & 0.001 \\
\hline CPRX & Excretion ratio of filtered load after proximal tubule & 0.2 \\
\hline CRAV & Arterial resistance/venous resistance & 5.93 \\
\hline CSM & Transfer coefficient of water from ECF to ICF & $0.00031^{2} / \mathrm{mEq} / \mathrm{min}$ \\
\hline DCLA & Chloride shift & $0 \mathrm{mEq} / \mathrm{l}$ \\
\hline DEN & Proportional constant between QCO and VB & 1 \\
\hline FCOA & Volume fraction of $\mathrm{CO}_{2}$ in dry alveolar gas & 0.0561 \\
\hline FCOI & Volume fraction of $\mathrm{CO}_{2}$ in dry inspired gas & 0 \\
\hline FO2A & Volume fraction of $\mathrm{O}_{2}$ in dry alveolar gas & 0.1473 \\
\hline FO2I & Volume fraction of $\mathrm{O}_{2}$ in dry inspired gas & 0.21 \\
\hline GFR & Glomerular filtration rate & $0.1 \mathrm{l} / \mathrm{min}$ \\
\hline GFR0 & Normal value of GFR & $0.1 \mathrm{l} / \mathrm{min}$ \\
\hline HF0-HF4 & Parameters related to the abnormal state of the heart & 0 \\
\hline HT & Hematocrit & $45 \%$ \\
\hline KL & Parameter of left heart performance & 0.2 \\
\hline KR & Parameter of right heart performance & 0.3 \\
\hline MRCO & Metabolic production rate of $\mathrm{CO}_{2}$ & $0.23181(\mathrm{STPD}) / \mathrm{min}$ \\
\hline MRO2 & Metabolic production rate of $\mathrm{O}_{2}$ & $0.2591 \mathrm{l}(\mathrm{STPD}) / \mathrm{min}$ \\
\hline OSMP & Plasma osmolality & $287 \mathrm{mOsm} / 1$ \\
\hline OSMU & Urine osmolality & $461 \mathrm{mOsm} / 1$ \\
\hline PAP & Pulmonary arterial pressure & $20 \mathrm{mmHg}$ \\
\hline PAS & Systemic arterial pressure & $100 \mathrm{mmHg}$ \\
\hline PBA & Barometric pressure & $760 \mathrm{mmHg}$ \\
\hline
\end{tabular}




\begin{tabular}{|c|c|c|}
\hline Symbol & Definition & Normal value \\
\hline PBL & PBA-Vapor pressure & $713 \mathrm{mmHg}$ \\
\hline PC & Capillary pressure & $17 \mathrm{mmHg}$ \\
\hline PCOA & $\mathrm{CO}_{2}$ tension in alveoli & $40 \mathrm{mmHg}$ \\
\hline PF & Filtration pressure & $0.3 \mathrm{mmHg}$ \\
\hline PHA & $\mathrm{pH}$ of arterial blood & 7.4 \\
\hline PHI & $\mathrm{pH}$ of intracellular fluid & 7.0 \\
\hline PHU & $\mathrm{pH}$ of urine & 6.0 \\
\hline PICO & Interstitial colloid osmotic pressure & $5.0 \mathrm{mmHg}$ \\
\hline PIF & Interstitial fluid pressure & $-6.3 \mathrm{mmHg}$ \\
\hline $\mathrm{PO} 2 \mathrm{~A}$ & $\mathrm{O}_{2}$ tension in alveoli & $105 \mathrm{mmHg}$ \\
\hline PPCO & Plasma colloid osmotic pressure & $28 \mathrm{mmHg}$ \\
\hline PVP & Pulmonary venous pressure & $4 \mathrm{mmHg}$ \\
\hline PVP0 & Parameter of left heart performance & $0 \mathrm{mmHg}$ \\
\hline PVS & Systemic venous pressure & $3 \mathrm{mmHg}$ \\
\hline PVSO & Parameter of right heart performance & $0 \mathrm{mmHg}$ \\
\hline QCFR & Capillary filtration rate & $0.002 \mathrm{l} / \mathrm{min}$ \\
\hline QCO & Cardiac output & $51 / \mathrm{min}$ \\
\hline QIC & Rate of water flow into intracellular space & $0 \mathrm{l} / \mathrm{min}$ \\
\hline QIN & Drinking rate & $0.001 \mathrm{1} / \mathrm{min}$ \\
\hline QIWL & Rate of insensible water loss & $0.0005 \mathrm{l} / \mathrm{min}$ \\
\hline QLF & Rate of lymph flow & $0.021 / \mathrm{min}$ \\
\hline QMWP & Rate of metabolic water production & $0.0005 \mathrm{l} / \mathrm{min}$ \\
\hline QPLC & rate of protein through capillary & $0.000799 \mathrm{l} / \mathrm{min}$ \\
\hline QVIN & Rate of intravenous water input & $01 / \mathrm{min}$ \\
\hline QWD & Rate of urinary excretion in distal tubule & $0.01 \mathrm{l} / \mathrm{min}$ \\
\hline QWU & Urine output & $0.001 \mathrm{1} / \mathrm{min}$ \\
\hline RTOP & Total resistance in pulmonary circulation & $3 \mathrm{mmHg} \cdot \mathrm{min} / \mathrm{l}$ \\
\hline RTOT & Total resistance in systemic circulation & $20 \mathrm{mmHg} \cdot \mathrm{min} / 1$ \\
\hline STBC & Standard bicarbonate at $\mathrm{pH}=7.4$ & $24 \mathrm{mEq} / \mathrm{l}$ \\
\hline TADH & Time constant of ADH secretion & $30 \mathrm{~min}$ \\
\hline TALD & Time constant of aldosterone secretion & $30 \mathrm{~min}$ \\
\hline THDF & Effect of third factor (ratio to normal) & 1 \\
\hline $\mathrm{UCOA}$ & Content of $\mathrm{CO}_{2}$ in arterial blood & $0.56121(\mathrm{STPD}) / \mathrm{l}$.blood \\
\hline UCOV & Content of $\mathrm{CO}_{2}$ in venous blood & 0.6075 l(STPD)/l.blood \\
\hline UHB & Blood $\mathrm{O}_{2}$ combining power & 0.21 .02 (STPD)/l.blood \\
\hline UHBO & Blood oxyhemoglobin & 0.21 .02 (STPD)/l.blood \\
\hline $\mathrm{UO} 2 \mathrm{~A}$ & Content of $\mathrm{O}_{2}$ in arterial blood & 0.20331 (STPD)/l.blood \\
\hline $\mathrm{UO} 2 \mathrm{~V}$ & Content of $\mathrm{O}_{2}$ in venous blood & 0.15151 (STPD)/l.blood \\
\hline VAL & Total alveolar volume & 31 \\
\hline VB & Blood volume & 41 \\
\hline VEC & Extracellular fluid volume & 111 \\
\hline VI & Ventilation & $5 \mathrm{l} / \mathrm{min}$ \\
\hline VI0 & Normal value of ventilation & $51 / \mathrm{min}$ \\
\hline
\end{tabular}




\begin{tabular}{|c|c|c|}
\hline Symbol & Definition & Normal value \\
\hline VIC & Intracellular fluid volume & 201 \\
\hline VIF & Interstitial fluid volume & 8.81 \\
\hline VP & Plasma volume & 2.21 \\
\hline VRBC & Volume of red blood cells & $1.8 \mathrm{1} / \mathrm{min}$ \\
\hline VTW & Total body fluid volume & 311 \\
\hline XCAE & ECF calcium concentration & $5 \mathrm{mEq} / \mathrm{l}$ \\
\hline XCLA & Arterial chloride concentration & $104 \mathrm{mEq} / \mathrm{l}$ \\
\hline XCLE & ECF chloride concentration & $104 \mathrm{mEq} / \mathrm{l}$ \\
\hline $\mathrm{XCO} 3$ & ECF bicarbonate concentration & $24 \mathrm{mEq} / 1$ \\
\hline XGLO & Reference value of ECF glucose concentration & $108 \mathrm{mg} / \mathrm{dl}$ \\
\hline XGLE & ECF glucose concentration & $6 \mathrm{mg} / \mathrm{l}$ \\
\hline XHB & Blood hemoglobin concentration & $15 \mathrm{~g} / \mathrm{dl}$ \\
\hline XKE & ECF potassium concentration & $4.5 \mathrm{mEq} / 1$ \\
\hline XKI & ICF potassium concentration & $140 \mathrm{mEq} / \mathrm{l}$ \\
\hline XMGE & ECF magnesium concentration & $3 \mathrm{mEq} / 1$ \\
\hline XMNE & ECF mannitol concentration & $0 \mathrm{mEq} / \mathrm{l}$ \\
\hline $\mathrm{XNE}$ & ECF sodium concentration & $140 \mathrm{mEq} / \mathrm{l}$ \\
\hline XOGE & ECF organic acid concentration & $6 \mathrm{mM} / 1$ \\
\hline XPIF & Interstitial protein concentration & $20 \mathrm{~g} / \mathrm{l}$ \\
\hline XPO4 & ECF phosphate concentration & $1.1 \mathrm{mM} / \mathrm{l}$ \\
\hline XPP & Plasma protein concentration & $70 \mathrm{~g} / 1$ \\
\hline $\mathrm{XSO} 4$ & ECF sulphate concentration & $1 \mathrm{mEq} / 1$ \\
\hline XURE & ECF urea concentration & $2.5 \mathrm{mM} / \mathrm{l}$ \\
\hline YCA & Renal excretion rate of calcium & $0.007 \mathrm{mEq} / \mathrm{min}$ \\
\hline YCAI & Intake rate of calcium & $0.007 \mathrm{mEq} / \mathrm{min}$ \\
\hline YCLI & Intake rate of chloride & $0.1328 \mathrm{mEq} / \mathrm{min}$ \\
\hline YCLU & Renal excretion rate of chloride & $0.1328 \mathrm{mEq} / \mathrm{min}$ \\
\hline YCO3 & Renal excretion rate of bicarbonate & $0.015 \mathrm{mEq} / \mathrm{min}$ \\
\hline YGLI & Intake rate of glucose & $0 \mathrm{mg} / \mathrm{min}$ \\
\hline YGLU & Renal excretion of glucose & $0 \mathrm{mg} / \mathrm{min}$ \\
\hline YINS & Intake rate of insulin & $0 \mathrm{U} / \mathrm{min}$ \\
\hline YKD & Rate of potassium excretion in distal tubule & $0.1205 \mathrm{mEq} / \mathrm{min}$ \\
\hline YKIN & Intake rate of potassium & $0.047 \mathrm{mEq} / \mathrm{min}$ \\
\hline YKU & Renal excretion rate of potassium & $0.047 \mathrm{mEq} / \mathrm{min}$ \\
\hline YMG & Renal excretion rate of magnesium & $0.008 \mathrm{mEq} / \mathrm{min}$ \\
\hline YMGI & Intake rate of magnesium & $0.008 \mathrm{mEq} / \mathrm{min}$ \\
\hline YMNI & Intake rate of mannitol & $0 \mathrm{mM} / \mathrm{min}$ \\
\hline YMNU & Renal excretion rate of mannitol & $0 \mathrm{mM} / \mathrm{min}$ \\
\hline YND & Rate of sodium excretion in distal tubule & $1.17 \mathrm{mEq} / \mathrm{min}$ \\
\hline YNH & Rate of sodium excretion in Henle loop & $1.4 \mathrm{mEq} / \mathrm{min}$ \\
\hline YNHO & Normal excretion rate of ammonium & $0.024 \mathrm{mEq} / \mathrm{min}$ \\
\hline YNH4 & Renal excretion rate of ammonium & $0.024 \mathrm{mEq} / \mathrm{min}$ \\
\hline YNIN & Intake rate of sodium & $0.12 \mathrm{mEq} / \mathrm{min}$ \\
\hline
\end{tabular}




\begin{tabular}{lll}
\hline Symbol & Definition & Normal value \\
\hline YNU & Renal excretion rate of sodium & $0.12 \mathrm{mEq} / \mathrm{min}$ \\
YOGI & Intake rate of organic acid & $0.01 \mathrm{mM} / \mathrm{min}$ \\
YORG & Renal excretion rate of organic acid & $0.01 \mathrm{mM} / \mathrm{min}$ \\
YPG & Flow of protein into interstitial gel & $0 \mathrm{~g} / \mathrm{min}$ \\
YPLC & Flow of protein through capillary & $0.04 \mathrm{~g} / \mathrm{min}$ \\
YPLF & Flow of protein in lymphatic vessel & $0.04 \mathrm{~g} / \mathrm{min}$ \\
YPLG & Flow of protein into pulmonary fluid & $0 \mathrm{~g} / \mathrm{min}$ \\
YPLV & Destruction rate of protein in liver & $0 \mathrm{~g} / \mathrm{min}$ \\
YPO4 & Renal excretion rate of phosphate & $0.025 \mathrm{mM} / \mathrm{min}$ \\
YPOI & Intake rate of phosphate & $0.025 \mathrm{mM} / \mathrm{min}$ \\
YSO4 & Renal excretion rate of sulphate & $0.02 \mathrm{mEq} / \mathrm{min}$ \\
YSOI & Intake rate of sulphate & $0.02 \mathrm{mEq} / \mathrm{min}$ \\
YTA & Renal excretion rate of titratable acid & $0.0168 \mathrm{mEq} / \mathrm{min}$ \\
YTA0 & Normal excretion rate of titratable acid & $0.0068 \mathrm{mEq} / \mathrm{min}$ \\
YURI & Intake rate of urea & $0.15 \mathrm{mM} / \mathrm{min}$ \\
YURU & Renal excretion rate of urea & $0.15 \mathrm{mM} / \mathrm{min}$ \\
ZCAE & ECF calcium content & $55 \mathrm{mEq}$ \\
ZCLE & ECF chloride content & $1144 \mathrm{mEq}$ \\
ZGLE & ECF glucose content & $66 \mathrm{mg}$ \\
ZKE & ECF potassium content & $49.5 \mathrm{mEq}$ \\
ZKI & ICF potassium content & $2800 \mathrm{mEq}$ \\
ZMGE & ECF magnesium content & $33 \mathrm{mEq}$ \\
ZMNE & ECF mannitol content & $0 \mathrm{mM}$ \\
ZNE & ECF sodium content & $1540 \mathrm{mEq}$ \\
ZOGE & ECF organic acid content & $66 \mathrm{mM}$ \\
ZPG & Protein content in interstitial gel & $20 \mathrm{~g}$ \\
ZPIF & ISF protein content & $176 \mathrm{~g}$ \\
ZPLG & Protein content in pulmonary fluid & $70 \mathrm{~g}$ \\
ZPO4 & ECF phosphate content & $12.1 \mathrm{mM}$ \\
ZPP & Plasma protein content & $154 \mathrm{~g}$ \\
ZSO4 & ECF sulphate content & $11 \mathrm{mEq}$ \\
ZURE & & $77.5 \mathrm{mM}$ \\
\hline & & \\
& &
\end{tabular}

\section{References}

Averina VA, Othmer HG, Fink GD, Osborn JW (2012) A new conceptual paradigm for the haemodynamics of salt-sensitive hypertension: a mathematical modelling approach. J Physiol 590:5975-5992. doi:10.1113/jphysiol.2012.228619

Beard DA, Mescam M (2012) Mechanisms of pressure-diuresis and pressure-natriuresis in Dahl saltresistant and Dahl salt-sensitive rats. BMC Physiol 12:6. doi:10.1186/1472-6793-12-6

de Bono B, Grenon P, Sammut SJ (2012) ApiNATOMY: a novel toolkit for visualizing multiscale anatomy schematics with phenotype-related information. Hum Mutat 33(5):837-848 
de Bono B, Hoehndorf R, Wimalaratne S, Gkoutos G, Grenon P (2011) The RICORDO approach to semantic interoperability for biomedical data and models: strategy, standards and solutions. BMC Res Notes 4:313

Guillaud F, Hannaert P (2010) A computational model of the circulating renin-angiotensin system and blood pressure regulation. Acta Biotheor 58:143-170. doi:10.1007/s10441-010-9098-5

Guyton AC, Coleman TG, Granger HJ (1972a) Circulation: overall regulation. Annu Rev Physiol 34:13-46

Guyton AC, Coleman TG, Cowley AW Jr, Liard JF, Norman RA Jr, Manning RD Jr (1972b) Systems analysis of arterial pressure regulation and hypertension. Ann Biomed Eng 1:254-281

Hernandez AI, Le Rolle V, Ojeda D, Baconnier P, Fontecave-Jallon J, Guillaud F, Grosse T, Moss RG, Hannaert P, Thomas SR (2011) Integration of detailed modules in a core model of body fluid homeostasis and blood pressure regulation. Progr Biophys Mol Biol 107:169-182. doi:10.1016/j. pbiomolbio.2011.06.008

Hucka M, Finney A, Sauro HM, Bolouri H, Doyle JC, Kitano H, Arkin AP, Bornstein BJ, Bray D, Cornish-Bowden A, Cuellar AA, Dronov S, Gilles ED, Ginkel M, Gor V, Goryanin II, Hedley WJ, Hodgman TC, Hofmeyr JH, Hunter PJ, Juty NS, Kasberger JL, Kremling A, Kummer U, Le Novere N, Loew LM, Lucio D, Mendes P, Minch E, Mjolsness ED, Nakayama Y, Nelson MR, Nielsen PF, Sakurada T, Schaff JC, Shapiro BE, Shimizu TS, Spence HD, Stelling J, Takahashi K, Tomita M, Wagner J, Wang J (2003) The systems biology markup language (SBML): a medium for representation and exchange of biochemical network models. Bioinformatics 19(4):524-531

Hunter P, Chapman T, Coveney PV, de Bono B, Diaz V, Fenner J, Frangi AF, Harris P, Hose R, Kohl P, Lawford P, McCormack K, Mendes M, Omholt S, Quarteroni A, Shublaq N, Skr J, Stroetmann K, Tegner J, Thomas SR, Tollis I, Tsamardinos I, van Beek JHGM, Viceconti M (2013) A vision and strategy for the virtual physiological human: 2012 update Interface Focus 3 doi:10.1098/rsfs.2013. 0004

Ikeda N, Marumo F, Shirataka M, Sato T (1979) A model of overall regulation of body fluids. Ann Biomed Eng 7:135-166

Karaaslan F, Denizhan Y, Kayserilioglu A, Gulcur HO (2005) Long-term mathematical model involving renal sympathetic nerve activity, arterial pressure, and sodium excretion. Ann Biomed Eng 33:1607-1630

Karaaslan F, Denizhan Y, Hester R (2014) A mathematical model of long-term renal sympathetic nerve activity inhibition during an increase in sodium intake. Am J Physiol Regul Integr Comp Physiol 306:R234-R247. doi:10.1152/ajpregu.00302.2012

Kofranek J, Lu Danh Vu, Snaselova H, Kerekes R, Velan T (2001) GOLEM-multimedia simulator for medical education. Proceedings of MEDINFO 2001. Stud Health Technol Inform 84:1042-1046

Min FB (1982) Computersimulatie en wiskundige modellen in het medisch onderwijs: Het RLCS System. $\mathrm{PhD}$ Thesis (in Dutch) University of Limbug, Maastricht

Min FB (1993) Fluid volumes: the program "FLUIDS". In: van Wijk van Brievingh RP, Möller DPF (eds) Biomedical modeling and simulation on a PC-A workbench for physiology and biomedical engineering. Springer, New York

Montani JP, Adair TH, Summers RL, Coleman TG, Guyton AC (1989) A simulation support system for solving large physiological models on microcomputers. Int J Bio-medical Comput 24:41-54

Montani JP, Van Vliet BN (2009a) Commentary on 'Current computational models do not reveal the importance of the nervous system in long-term control of arterial pressure'. Exp Physiol 94:396-397

Montani JP, Van Vliet BN (2009b) Understanding the contribution of Guyton's large circulatory model to long-term control of arterial pressure. Exp Physiol 94:382-388

Moss R, Grosse T, Marchant I, Lassau N, Gueyffier F, Thomas SR (2012) Virtual patients and sensitivity analysis of the Guyton model of blood pressure regulation: towards individualized models of wholebody physiology. PLoS Comput Biol 8:e1002571. doi:10.1371/journal.pcbi.1002571

Moss R, Kazmierczak E, Kirley M, Harris P (2009) A computational model for emergent dynamics in the kidney. Philos Trans A Math Phys Eng Sci 367:2125-2140. doi:10.1098/rsta.2008.0313

Moss R, Thomas SR (2014) Hormonal regulation of salt and water excretion: a mathematical model of whole-kidney function and pressure-natriuresis. Am J Physiol Renal Physiol. doi:10.1152/ajprenal. 00089.2013

Osborn JW, Averina VA, Fink GD (2009a) Current computational models do not reveal the importance of the nervous system in long-term control of arterial pressure. Exp Physiol 94:389-396. doi:10.1113/ expphysiol.2008.043281 
Osborn JW, Averina VA, Fink GD (2009b) Commentary on 'Understanding the contribution of Guyton's large circulatory model to long-term control of arterial pressure'. Exp Physiol 94:388-389. doi:10. 1113/expphysiol.2008.046516

Thomas SR, Baconnier P, Fontecave J, Francoise JP, Guillaud F, Hannaert P, Hernandez A, Le Rolle V, Maziere P, Tahi F, White RJ (2008) SAPHIR: a physiome core model of body fluid homeostasis and blood pressure regulation. Philos Trans A Math Phys Eng Sci 366(1878):3175-3197

Thomas SR (2009) Kidney modeling and systems physiology Wiley interdisciplinary reviews: systems. Biol Med 1:172-190 